$\begin{array}{ll} & \text { Etnográfica } \\ \text { etnográfica } & \text { Revista do Centro em Rede de Investigação em }\end{array}$

Antropologia

vol. $22(3) \mid 2018$

Vol. 22 (3)

\title{
Exploring the power of the written word: on hospital birth and the production of birth narratives
}

Explorando o poder da palavra escrita: parto hospitalar, conversas fiadas e a produção de narrativas de maternidade

\section{Elizabeth Pilar Challinor}

\section{(2) OpenEdition}

\section{Journals}

Electronic version

URL: https://journals.openedition.org/etnografica/6077

DOI: 10.4000/etnografica.6077

ISSN: 2182-2891

\section{Publisher}

Centro em Rede de Investigação em Antropologia

\section{Printed version}

Date of publication: 1 October 2018

Number of pages: 669-690

ISSN: 0873-6561

\section{Electronic reference}

Elizabeth Pilar Challinor, "Exploring the power of the written word: on hospital birth and the production of birth narratives", Etnográfica [Online], vol. 22 (3) | 2018, Online since 10 October 2018, connection on

21 January 2022. URL: http://journals.openedition.org/etnografica/6077 ; DOI: https://doi.org/

10.4000/etnografica.6077

\section{(c) (7) \&)}

Etnográfica is licensed under a Creative Commons Attribution-NonCommercial 4.0 International License. 


\section{Exploring the power of the written word: on hospital birth and the production of birth narratives}

\section{Elizabeth Pilar Challinor}

The events surrounding the expectations and experiences of a hospitalised childbirth in Northern Portugal are presented as an auto-ethnography, written in 2004, in the format of a diary and commented upon with hindsight by the author. The original motivation for writing the diary was to re-gain a degree of power over the birth process which, even before going into labour, the author felt she had already lost in comparison to her previous experiences of homebirth abroad. The diary elucidates how notions of childbirth and maternity care circulate in the social imaginary, moulding women's expectations. It also illustrates how maternity care in Northern Portugal in the decade 2000 was governed by the authoritative knowledge of biomedicine. Reflections in the diary on the potentially liberating role of auto-ethnography are re-examined in the article through a discussion of the research potential for promoting the writing of birth narratives.

KEYWORDS: childbirth, pregnancy, authoritative knowledge, medicalization, auto-ethnography.

Explorando o poder da palavra escrita: parto hospitalar, conversas fiadas e a produção de narrativas de maternidade - Os eventos que cercam as expectativas e experiências de um parto hospitalizado no Norte de Portugal são apresentados como uma autoetnografia, escrita em 2004, no formato de um diário e comentado em retrospetiva pela autora. A motivação original para escrever o diário era voltar a ganhar um grau de poder sobre o processo do nascimento que, mesmo antes de entrar em trabalho de parto, a autora sentiu que já havia perdido em comparação com as suas experiências anteriores de parto em casa no estrangeiro. O diário elucida como noções de parto e cuidados de maternidade circulam no imaginário social e moldam as expectativas das mulheres e ilustra como os cuidados de maternidade no Norte de Portugal na década 2000 foram governados pela autoridade do conhecimento da biomedicina. Reflexões no diário sobre o papel potencialmente libertador da autoetnografia são reexaminadas no artigo, através de uma discussão sobre o potencial da investigação para promover a escrita de narrativas do nascimento.

PALAVRAS-CHAVE: parto, gravidez, autoridade do conhecimento, medicalização, autoetnografia.

CHALLINOR, Elizabeth Pilar (e.p.challinor@gmail.com) - Centro em Rede de Investigação em Antropologia, Universidade do Minho (CRIA-UMinho), Portugal. 


\section{INTRODUCTION}

Does writing hold the potential for increasing women's agency in pregnancy and childbirth? This constitutes the underlying question posed by the narrative presented below, written in 2004, in an attempt to gain a sense of power over the impending birth of my third child, in an unfamiliar hospital setting in Northern Portugal. ${ }^{1}$ Even before going into labour, I already felt disempowered in comparison to my previous experiences of homebirth in the UK.

Although the narrative was written in the form of a diary, it also addressed an imaginary public, which suddenly became real when I was invited to present the narrative at the School of Nursing in Vila Real in January 2006. This was part of a research proposal to encourage not only mothers to write birth narratives, but also doctors and nurses to write narratives of the births they assisted. The presentation in Vila Real set in motion a number of public presentations, including one for in-service training for nurses in the hospital where the birth had taken place and in the seminar on "Pregnancy and childbirth reframed: anthropological perspectives from Portugal" which has resulted in this dossier. A shorter version of my birth narrative was also translated into Portuguese (Challinor 2012). ${ }^{2}$

What started out as a private writing project became public. Yet, as the tone and contents of the text below demonstrate, I always wrote with an audience in mind - quoting the academic literature, playing with my identity as both expectant mother and inquisitive anthropologist. Writing may be a solitary process but are we truly alone when we write? I would argue that the awareness of the presence of others influences the writing process of even the most personal of texts because the imaginary public includes the writer's reflexive, critical self in "a presentation of self to self" (Butz and Besio 2009: 1660). It is for this reason that writing about pregnancy and childbirth holds the potential for critical and political reflection, which may lead to an increased sense of personal agency. In her research with Brazilian women, O'Dougherty claims that their "unvoiced objections to C-section delivery, and the retrospective evaluations they made in their narratives, offer a belated, moral recuperation of agency" (2013: 58).

Perceptions also change over time. This highlights one of the difficulties of discussing one's own narrative written over a decade ago: it makes no sense to alter the original text, even if I no longer identify with all of its contents, just as it would make no sense to alter the contents of ethnographic field notes. The narrative has nonetheless been edited in terms of word length and clarity

I The writing and publication of this article is incorporated within the strategic project of CRIA (UID/ANT/04038/2013).

2 The discussion on writing an auto-ethnography has not been published in the Portuguese version, which also includes episodes that have been omitted in this version due to the word limit. 
and observations made at a later date have been placed in footnotes and in the narrative under the title "Commentary."

\section{FEAR, RISK AND AUTHORITATIVE KNOWLEDGE}

Inspired by the edited volume of Brochner and Ellis (2002), I referred to my narrative as an "auto-ethnography," which Reed-Danahay (1997: 9) describes as "a form of self-narrative that places the self within a social context." Further, Butz and Besio (2009: 1660) describe auto-ethnography as deliberate, self-conscious identity work carried out "in order to understand or represent some worldly phenomenon that exceeds the self." I disagree with Ingold's (2014: 385) statement that auto-ethnography is oxymoronic because "there are no people to describe but only the self" since the self in isolation is indeed an empirical impossibility.

My principal motivation for writing the birth narrative was not academic: it was to recuperate the sense of agency I had enjoyed in homebirths. Locating my experience of hospital birth in the wider Portuguese setting was not a priority at the time. I attempt to redress this here.

Hospitalised childbirth is viewed by Portuguese obstetricians as "a triumph of progress" (see White and Queirós, and Fedele, this volume). In 1956 80\% of births reportedly took place at home (De Luca, this volume) compared to 1996, when 98.3\% took place in hospital (Joaquim 2006: 77). These statistics are accompanied by a steady decrease in maternal mortality - the average annual rate of reduction between 1990 and 2015 was $2.1 \%$, with a total of 20 maternal deaths in 1990 compared to 8 in $2015 .{ }^{3}$ It is not surprising therefore that doctors equate safety in birth with hospitalization.

Public discourses about birth and the sharing of positive and negative birth experiences mould women's perceptions of what constitutes a "natural," "normal" or "risky" birth process and condition their expectations (Thomson et al. 2017). Research has also shown that severe fear of childbirth may increase the possibility of caesareans (Fenaroli et al. 2016; Ryding et al. 2015) as women become afraid of birthing their own babies physiologically (Kay 2016) and prefer to give way to the "authoritative knowledge" (Jordan 1993 [1978]) of the medical profession. This term was coined and explained by Jordan as follows:

"for any particular domain, several knowledge systems exist, some of which, by consensus, come to carry more weight than others, either because they explain the state of the world better for the purposes at hand, or because they are associated with a stronger power base" (1993 [1978]: 152). 
The idea of "authoritative knowledge" became a central concept for making sense of my experience of hospital birth in Portugal. The research carried out by Carapinheiro (1998) in two hospitals in Lisbon in the 1990s corroborates the relevance of this concept for the Portuguese medical context. She describes Portuguese clinical medical encounters as a form of symbolic violence, legitimated by the social and moral authority that doctors enjoy as a result of the medical knowledge that they possess, allowing them to exercise unquestioned power. Carapinheiro claims that whilst the doctor's knowledge is central (or sacred), the nurse's knowledge is considered to be peripheral and the patient's knowledge is dismissed as profane (1998: 279). More recent research in Portugal has revealed similar hierarchical relationships between those involved in the provision and reception of hospitalised maternal care (White 2016; White and Schouten 2014) and how a small number of women do choose privately funded homebirths as a means of rejecting the hegemony of biomedicine (Santos 2014; see also Fedele, this volume).

Yet, even in England, where homebirths are supported by the state and women have enjoyed two decades of high-level policy support for them to choose their place of birth (DH 1993, 2007), the authors of a longitudinal narrative study of pregnant women at three maternity services claim that for most women in the study, hospital birth was still closely associated with safety and they did not raise concerns about excessive medical intervention. The authors conclude that planning for birth is mediated by historical and cultural associations between birth and safety, further reinforced by contemporary discourses of risk, blame and responsibility (Coxon, Sandall and Fulop 2014). Midwives are also affected, torn between their attempts to encourage the mother to trust in her embodied ability to give birth to her baby spontaneously, and to administer risk-focused tests and measurements (Scamell 2011). Scamell's ethnographic study in South-East England reveals how midwives' sense of danger and risk - amplified through the increased use of surveillance technologies during labour and birth - limits their clinical practice and undermines their confidence, as exemplified in the following quote: "Us midwives: we are like swans swimming across a lake. On the top we look all serene and tranquil but under the water our little feet are flapping about like mad" (Scamell 2011: 987).

In the attempt to control my anxieties regarding hospital birth, rather than hidden flapping feet, I had a secretly scribbling pen! My description of events was, in places, purposely ironic and playful; perhaps this was a way of gaining a distance and hence more emotional control, as I was able to situate what was happening to me within wider discourses and power structures. O'Dougherty (2013: 59) describes a similar process of trying to retain agency and create meaning in the narratives of Brazilian women which enabled her to appreciate their "strength, humor, critical edge, and creativity" and which lead her to conclude that individual experiences provide compelling ground for social change. 


\section{BEHOLD THE MOUNTAIN}

\section{SEPTEMBER 2004}

Where does the birth narrative of my third child begin? In many ways, it begins in the memories of the births of my first and second children - homebirths in Brighton, UK, with midwives attentive to my needs. ${ }^{4}$ This time it will be different. I now live in a small town in Northern Portugal and a homebirth is out of the question. But that doesn't concern me too much since my age ${ }^{5}$ would probably make it forbidden in the UK too. The real issue, I have recently discovered, with enthusiasm and a degree of comfort, has been addressed in the edited volume by Davis-Floyd and Sargent (1997) on "childbirth and authoritative knowledge." The real issue is that, as far as I can make out, women's experience of childbirth in Portugal is one of total submission to the authority of their doctors. And there is good reason for my use of the possessive pronoun. Here, at least, in this Portuguese town, women shun the family doctors of the National Health Service, finances and/or health cover permitting, and prefer to "go private." Every month they are assisted by their obstetricians, many of whom work in the state hospital but also work in private clinics. As the due date approaches, negotiations begin regarding when the baby will be born: most women want to be assisted by their obstetricians in the hospital and so Dr. So and So's "private" babies, for example, are all born on Thursday afternoons. Inducing birth is not the best way to begin an active birth, but no matter; practically no-body has heard of an active birth, at least not in this town. Balaskas describes it as an attitude of mind:

"It involves acceptance and trust in the natural function and involuntary nature of the birth process, as well as an attitude or appropriate positioning of your body. It is not merely a vaginal extraction or delivery in which the attendants are in control and you are a passive patient" (Balaskas 1991: 2).

In this town women give birth lying flat on their backs on the hospital beds, legs possibly up in stirrups. This is hard for me to swallow, since I know that at least in some hospitals in the UK I would still be allowed to give birth in an upright position. My two daughters were born in the living room - no bed in sight. More importantly,

4 Homebirths in the UK are provided by the National Health Service free of charge. A midwife visits the woman in her home prior to the birth to make all the necessary arrangements. For more information, see < http://www.which.co.uk/birth-choice > (last access in October 2018).

5 I was 39 at the time and recalled having been told that homebirths were not permitted in the UK after the age of 35. The birth choice internet tool which has since been devised to help women make informed choices of where to give birth - see footnote 4 above - does not rule out homebirth for women over 40 . 
I was encouraged to write a birth plan, ${ }^{6}$ so that many of the details of the actual birth process were decided upon in negotiation with the health professionals. No-body has ever heard of a birth plan here. Doctors know best.

The birth narrative of my third child continues with a reconnaissance appointment with an obstetrician, whom I have been told, may be sensitive to my concerns. No, he has never heard of an active birth. I have taken along a book - New Active Birth: A Concise Guide to Natural Childbirth, by Janet Balaskas (1991) - but he is only mildly interested in looking at it. Nevertheless, we talk for a long time, challenging each other's positions. He displays a degree of openness to my arguments. I show him pictures from the book which demonstrate how the sacrum and coccyx are freer to move in an upright position, consequently allowing the pelvic outlet to open to the maximum, whereas when a woman is lying on her back this closes the pelvic outlet rendering the birth more difficult and painful (Balaskas 1991: 24-25). Unable to remember the Portuguese word for "crouching," I give him a quick demonstration of how I gave birth before and he replies "oh yes, like savages." Unable to conceal my surprise at his remark, I reply "well that's one way of putting it." The discussion continues. "Oh yes," "episiotomies are routine," he always conducts them to avoid "bad tearing." 7 He's not convinced by my alternative suggestions such as rubbing in almond oil to increase the elasticity of the perineal area. "But what happens if you have a really bad tear? I'm the one that has to operate on you." I decline to argue back that natural tearing is often much more superficial than the deep cut of an episiotomy since, in both instances, I tore relatively badly and I sense an awakening to the idea of experimenting with his alternative approach.

We have talked for a long time and it has now come to the crunch. If I want my active birth, I will still have to be induced because he only works in the hospital Wednesday afternoons. He likes to develop a relationship with the pregnant women he cares for and so he always tells them it's their choice: if they want to be sure that he will be the doctor assisting them at the birth, then it has to be pre-arranged. I feel tempted; it already feels like we have struck up some kind of relationship. He glances down at my medical notes and then gets up to see me to the door. Just before he opens it, he says "I'm sorry about what I said earlier." I look at him, perplexed. "You know, about the savages, I've just realized you're an anthropologist..."

A few days pass by and the charm wears off. No, I don't want to be induced - it goes against all the principles of an active birth. The obstetrician had argued that

6 In the UK it is common for women to write a birth plan during pregnancy, which is discussed with midwives and shared with the health professionals who attend her during birth.

7 The relative merits of natural tearing versus episiotomy have long been debated in the medical literature. A study of variations in rates of severe perineal tears and episiotomies in 20 European countries (Blondel et al. 2016) reveals a negative correlation between the rates of episiotomies and severe tears. Episiotomy rates in most European countries ranged between 16 and $38 \%$ of all vaginal deliveries, with Portugal amidst the countries with the highest rates of over $60 \%$. 
as long as the cervix was ripe he really couldn't see what the problem was. But I have read that in induced births, contractions come more suddenly and far stronger, undermining the mother's capacity to "go with the flow," as the force of the contractions gradually builds up. But there is another issue at stake here. I can't help feeling angry and defiant: why should I, and more importantly my baby, submit to his timetable? No! I don't want a conveyer belt birth. I recall talking to a mother in the park whose baby was born just before Christmas, "nineteen babies were born that day," she tells me, "because the next day the doctors were starting their holidays."

I return to the health centre and continue the subsidized appointments with my family doctor. She is sweet enough and does everything by the book. In fact she is so concerned to get it all right that usually when I walk in to the consultation room she doesn't even look at me: her face remains glued to the computer screen as she checks out my medical record. ${ }^{8}$

Time goes by and my pregnancy is now public knowledge. People's eyes in the street are drawn to my bump like magnets and friends and acquaintances congratulate me, admire my "courage" in having a third child. ${ }^{9}$ As time passes by, I start to feel more anxious about how the birth will be in hospital with hardly any say over the whole process, most possibly with doctors I have never met. This anxiety eats at me quietly until one day, I cannot recall when or why, I have a new idea. Why not write my own birth narrative? Surely this will help me to accept what comes with less anger and maybe to take things less personally. It will enable me to approach the whole process with a degree of detachment. A quick Internet search produces two titles which make me believe in serendipity: the volume entitled Childbirth and Authoritative Knowledge (Davis-Floyd and Sargent 1997) referred to above and Ethnographically Speaking, edited by Brochner and Ellis (2002). The latter becomes addictive bedtime reading and keeps me awake at night! The volume's approach to auto-ethnography seems to coincide with my own intuition regarding the healing potential of narratives whilst, at the same time, cautioning against narcissism. Lesa Lockford, for example, claims that

“... in order for writing that takes the self as its subject to not be merely some vain, narcissistic act it must have two characteristics: First, 'the story told [should] point beyond the self' and, second, it should 'remind you that consequences happen on an individual level...[that] politics only matter as they unravel in individual lives, and individual lives only matter when they can make a political difference'” (Pelias 1999: 165, in Lockford 2002: 81-82).

8 See a similar scenario described in Fedele, this volume.

9 Portugal's fertility rate is one of the lowest in Europe. See < http://ec.europa.eu/eurostat/statistic s-explained/index.php?title=File:Fertility_indicators,_2016.png > (last access in October 2018). 
The experience of pregnancy and childbirth is a political issue, which I hope my birth narrative may also address. There are still two months to go before my due date and I also feel it is important to write this part of the narrative before the birth so that I can compare the birth experience with my initial impressions, and indeed prejudices, of how I thought it would be. After all, each birth is different even within the same health service.

\section{SEPTEMBER}

I took one more appointment with the obstetrician and my husband came along too. I fired him with questions about what birth is like in the local hospital and although it was a very pleasant appointment, I have now made the absolute final decision that I don't want to induce the birth. The next step is to have a chat with a midwife I know, who used to work at the hospital and now teaches at the local nursing school. It has occurred to me that she might be able to let me see the ward beforehand, which would probably help to put me more at ease. In the meantime, acquaintances continue to share their birth stories with me. Yesterday, I was told by a woman how she had requested an epidural which was injected directly into her veins by mistake. Surprised at her ability to feel the contractions, she was able to feel herself push the baby out and only discovered later that she was lucky to be alive!

\section{SEPTEMBER}

I bumped into the midwife and seized the opportunity to have a chat. She suggested that I call her when I go into labour - any hour of the day or night. I am moved and reassured by her readiness to help, especially since she emphasized that there is no guarantee that my husband will be able to be present; if the ward is busy then he may not be allowed in!

We also spoke about active birth and she claimed that it will probably be difficult for me to give birth in a more upright position because nobody has heard of such a thing and it would "disorient" the medical staff should I request it. I still cherish a secret hope that when the moment comes I will somehow be able to do it my way. Nonetheless, she has also warned me that they are very likely to put me on an intravenous drip! ${ }^{10}$

Bedtime reading is now about women's submission to the authoritative knowledge of biomedicine. The article on issues of choice and control in American childbirth raises a crucial point when it claims that women who assert themselves may be resented by hospital staff and even given inferior treatment.

"I get angry because... [t]hey still want an unwritten guarantee that they are going to have a healthy baby with no interventions, and I can't provide that. I tell them that I think monitoring is real important" (Lazarus 1997: 148).

10 This is usually used to induce labour with the labour-provoking drug oxytocin. 
It seems to me that an angry birthing woman, together with annoyed and angry medical staff, is not the best reception for a newborn! So although I have not given up my bedtime reading, I am reading in smaller doses and with a view to finding my own personal strategy through all of this. I can't agree more with the observation that healthy babies and minimal intervention is not an "either/or situation" (Trevathan 1997: 84).

It has occurred to me that it is ironic that I appear to be doing things in reverse. Many women who have homebirths will do so after having had their first child in hospital. Fearful though I was during my first pregnancy, it was thanks to preparation classes in Brighton with the $\mathrm{NCT}^{11}$ that I developed the desire and the courage to have a homebirth. At the beginning of the pregnancy, my husband had nonchalantly suggested a homebirth, since he was born at home in a small village in Northern Portugal in the late 1950s, when hospital births were not yet the norm in rural Portugal. I was horrified by the idea. However, after becoming more informed through the NCT preparation classes, I began to warm to the idea. Needless to say, I would never have had the courage to have a homebirth if it hadn't been for our NCT "teacher" who offered to be present throughout the birth. When it came to the birth of our second child, I didn't even give hospital birth a thought.

\section{SEPTEMBER}

I went for my final scan today. I had been warned that I would have to wait quite a long time so I decided to take the book Ethnographically Speaking (Brochner and Ellis 2002). As I noted yesterday, I need a way out of this "anger impasse": a means of moving beyond my anticipated anger at having to relinquish control of the birthing experience.

"If you think of understanding as a reductive process, then not understanding opens up opportunities for renewed curiosity [...] Gregory Bateson used to talk about the problems of 'explanatory principles.' When you think you've got a handle on something, got it explained, you stop being curious about it" (Ellis and Flemons 2002: 348).

Surely this is a way out: to cultivate my curiosity about what this completely different birth experience will be like. This has also made me acknowledge, once again, that I do have a very fixed idea about how "bad" this experience is going to be. Prejudging the event is no good for the mother or for the researcher!

11 The National Childbirth Trust, a UK-based charity which offers information and support in pregnancy, childbirth and early parenthood, including antenatal classes (see < www.nct.org.uk $>$, last access in October 2018). 
Will it be possible to have dialogue with the medical staff? In other words, do I have to choose between total submission to the authority of the hospitalized medical system or adamant resistance? Could there be a third option? This reminded me of a point raised by Jordan.

"What if labour rooms built in the possibility of transforming papered walls into large interactive information displays that could show, in graphic and comparative form, what is known about the state of the labour on the basis of physical examinations, monitor outputs, and test results? What if such displays were routinely used for generating conversations between the woman, the medical staff, and the woman's attendants - that is the people concerned with making the birth successful? It would be during such conversations that... alignment could be sought between what the woman experiences and what the machines show, and joint decisions could be made based on the best available evidence from all sources" (Jordan 1997: 73).

Jordan's hopeful vision has also prompted me to speculate. What if the midwife, who has so kindly offered to accompany me, is able to serve as a bridge between my perspective and that of the medical staff? What actually happens on the day cannot be anticipated, but, already, I can feel that fear is giving way to curiosity...

\section{OCTOBER}

I now know what it feels like to be wired up to a fetal monitor. I was left for twenty minutes lying on a couch listening to the amplified sound of the baby's heartbeat and every time I felt the baby move I had to press a little button. The nurse told me that it is customary to be wired up throughout the first stage of labour. "I won't be able to move around with this" I commented, "oh no," she replied, "not a lot of movement goes on." She also told me that the amount of time spent wired up does depend to some degree on individual midwives and doctors - giving me some hope that I will be able to negotiate a relatively more active birth.

I recall attending yoga-based classes for pregnant women in the UK where I learnt how the feeling of fear can increase pain. I experienced saying "yes" in my mind while I sat, legs crossed, bearing the weight of a woman's legs on my own. "Now say 'no'," exclaimed the teacher and her legs suddenly felt heavier and I began to feel pain.

In one of these sessions, I remember hearing a woman remark that before the birth it feels like you are facing an enormous mountain, but that after the birth, life rolls on like a never ending plain. With more or less a month to go, I feel like I am approaching the foot of the mountain: I'm looking forward to setting my feet upon the plain. 


\section{OCTOBER}

I went to buy a new teapot and, once again, found that my cumbersome presence prompted the woman who attended me to share her unsolicited birth story. Having only recently experienced the fetal monitor for myself, and consequently having chosen to read more about it, I was intrigued to discover how her account corroborated the point made by Davis-Floyd that the routine use of the fetal monitor conveys the message to birthing women that their bodies are not to be trusted (Davis-Floyd 1992, in Wagner 1997: 379). Apart from measuring the baby's heartbeat, the monitor also measures contractions. This woman told me how she had arrived at the maternity ward full of pain only to be sneered at by the obstetrician because, according to the monitor, she wasn't having any contractions. He told her the baby would only be born in a week or two. Nevertheless, he decided to look at her scans and was annoyed to find that she had only brought the last one with her. Since her home was near the hospital, she suggested that her husband go to fetch it and in the following half hour during her husband's absence, her baby was born. She also gave me a detailed description of how she had suffered the complication of a ruptured placenta.

How many more stories will I hear before I have my own to tell? The ease with which this woman, whom I barely knew, passionately shared her unsolicited story with me suggests that she carried negative pent up feelings about the birth around with her. I wonder how many stories of frustration and anger are locked away: every person is somebody else's birth story. It came as no surprise to me that this particular woman ended her account with the usual "all's well that ends well," because baby was healthy, (although I couldn't help but note her grudging tone). One of the most powerful tools of the biomedical model for disciplining women's bodies, in Foucault's (1991) sense of the word, is the safety of the baby. It is easy to make women feel guilty for desiring such "trivial" things as a more natural connection with their own bodies and a positive birth experience.

\section{Commentary: "idle talk" and the medical management of birth}

The sharing of birth stories between women is examined from a Heideggerian perspective by Kay (2016) who argues that they are often constructed through "idle talk," which is composed of taken for granted assumptions of how things are, much of which may be groundless and yet appear to be authoritative, influencing women's expectations and consequent experiences of birth.

"[Heidegger] suggests that we do not 'so much understand the entities which are talked about' but rather that we concentrate on what is claimed about the entity; 'we already are listening only to what is said-in-the-talk as such' $[\ldots]$. We accept what is claimed, simply because it is said, and we 
pass it on, further disseminating the claim. The result, Heidegger tells us, is that "what is said-in-the-talk as such, spreads in wider circles and takes on an authoritative character. Things are so because one says so' " (Kay 2016: 212).

Kay's findings that most of the "idle talk" around birth in the UK was focused on "the medically managed and negative experiences of birth as opposed to the joyous sharing of a positive experience" (2016: 193) are also corroborated in this narrative, since nobody shared a positive birth experience with me. Kay argues that the favoring of negative birth stories over positive ones in everyday conversations and the popular media, serves to accentuate childbirth as a medical event, which needs to be managed, rather than as an emotionally embodied experience.

The obstetrician I consulted also alluded to the importance of emotions, stating that he tried to develop a relationship with his patients. Ironically, for this to be possible, the birth had to be pre-arranged and was hence more likely to be medically managed. This begs the questions posed by Martin (1987: 148): "whose baby, whose life, whose birth, whose timing, and who has the power to decide?" Martin notes that in the United States, women's ability to resist aspects of medical treatment they dislike is affected by their race and their class. Yet, in her study of the childbirth narratives of middle-class Brazilian women, O’Dougherty (2013) argues that class privilege does not lead to choice over the mode of childbirth delivery. Access to private obstetrical care in Northern Portugal reduced women's chances of experiencing spontaneous labour and increased the possibilities of experiencing more medical intervention.

\section{OCTOBER}

A friend invited me to attend a seminar at the local nursing school on childbirth. The first session I attended was a very detailed exposition of how to administer an epidural, including a discussion of the benefits and risks. The speaker was an anaesthetist from the local hospital who firmly believed that the benefits far outweighed the risks and concluded her presentation by claiming that epidurals should be available to everybody because they constitute the best option of pain relief available. The final presentation was poles apart: a discussion and a film on water births in Belgium. The midwife, who presented the film, had worked for nine years in Luxembourg and she spoke my language: positive birth experience, respecting the natural rhythms of birth, the role of the natural production of endorphins, not only in pain relief but in experiencing the overwhelming emotions of love and joy at the sight of the newborn. She also spoke of what a shock it had been for her to come back and work in Portugal where women's wishes in childbirth are barely taken into account. 


\section{NOVEMBER}

I came away a happy bunny from my doctor's appointment yesterday because I realized that, having reached forty weeks of pregnancy, I was reaping the benefits of avoiding private obstetrical care: no emotional pressure to induce labour in order to coincide with the doctor. However, I am also aware that my experience will not be representative of the average woman who is anonymously assisted through the subsidized National Health Service because I have a guardian angel: a midwife who knows just about everybody in the hospital who has offered to be "on call" for me 24 hours a day. So the mother-to-be can relax even if the researcher feels slightly guilty that somehow she may be cheating!

Although I am adamant that I don't wish to induce labour, I must confess that impatience is getting the better of me. Here I am, at the foot of the mountain, geared up for the climb and nothing is happening. I don't intend to write again until I have come back down the other side.

\section{THE ROLLING PLAINS}

\section{NOVEMBER}

I had not been prepared for the emotional experience of emerging triumphantly from the hospital entrance with my newborn baby into the big wide world. Although everybody was going about their business as usual, I felt that a red carpet and trumpets were called for. No-body turned their heads! No matter! I could feel a lump in my throat as I walked into the brisk sunny day with baby wrapped up in my arms. We had a baby boy!

It all began on the morning of 15 November when I started to have contractions in bed. At around 6.00 am I got up and ate some bread with tahini and then went back to bed. At this stage I was dozing through the intervals of each contraction but by the time the alarm clock went off at 8.00 am I was absorbed with breathing through each contraction and informed my husband that as soon as he had left the girls at school he should come back to take me to hospital. However, things started to move more quickly: I could feel a trickle and went to the bathroom to investigate. Blood! I called out for my husband to bring me the mobile phone to ring my guardian angel. I could hear the girls chattering as they got ready for school. My guardian angel said that I should start going to hospital just in case I was having a detached placenta. I felt a little panicky and went quickly into the bedroom to get dressed. I called out to my husband who was in the kitchen fixing breakfast for the girls.

I could feel the contractions coming thicker and faster. I sneaked into the kitchen to eat some bread for breakfast. I knew that I should be eating 
more ${ }^{12}$ but nerves were getting the better of me as I waited for the girls to be ready for school.

Finally, we reached the hospital. I refused to be dropped off by my husband at the emergency entrance because I wanted him to come with me and so we parked the car in the car park together and then walked down a sloping road to the hospital. It was a bright sunny day and we had a beautiful view of the town. I had to keep stopping to breathe through contractions and it reminded us both of the birth of our first daughter in which part of the first stage of labour was spent in sunny Preston Park just opposite our flat.

"We needn't go in just yet," joked the confident father, but I was still in a hurry and as we approached the emergency entrance, I could see that my midwife friend was there waiting for me. She took us quickly through the bureaucracy, explaining to hospital officials that birth was imminent. They wanted me to go on a stretcher or wheel chair but I said that I wanted to walk and the three of us walked the length of the corridor to the lift. There were a number of people inside the lift, including one of the obstetricians on duty that morning. She and my guardian angel took me straight into a room to be examined while my husband waited outside. The obstetrician announced that I was already eight centimetres dilated and that birth was imminent. Another woman present in the room, who I realized later was her attendant midwife, asked me if I felt the urge to push. I certainly did! I had already felt the urge in the car on the way to school. I can't recall whether it was the midwife or the obstetrician who said that I could now go straight to the delivery room and start pushing. I remember feeling surprised that I wasn't told to wait until I was ten centimetres dilated; but the urge to push was so strong I dismissed this concern from my mind.

\section{DECEMBER}

I climbed on to the narrow delivery bed which was situated in the middle of a small square room and was told to take off my clothes and put on a kind of overall. Although the bed was equipped with stirrups and bars along each side to hold on to, I was feeling calm and assured because the midwife had spoken a few empathetic words with me before hand. My guardian angel must have told her something because after an unexpected semi-shaving ${ }^{13}$ to which I protested in dismay, the midwife smiled and declared that she knew that I wasn't used to all these hospital procedures and wanted to do things more naturally. So although the delivery bed was a poor substitute for a sofa, cushions and a protected floor; I was not forced to put my legs up in stirrups or even to go on the drip. The obstetrician

12 During the presentation in Vila Real, this comment provoked a lot of laugher in the audience, since hospital policy is that women should not eat during labour in case they need a caesarean section. 13 The justification for shaving pubic hair is that it reduces the risk of infection when an episiotomy is performed or the perineum tears during labour. 
on duty said that she would allow me to forego the drip for the moment but that after birth she would have things her way. Once she had left the room the midwife explained to me that the drip after birth was to ensure a quick delivery of the placenta.

My husband had by now also been called into the room dressed in a white coat. He was the only male to assist in the birth. An unidentified woman was also present throughout the birth. All I can recall of her is that she looked on with an expression of surprise and what felt like mild disapproval as I tried to do things my way. The bed was uncomfortably narrow and high above the floor, yet I was still able to remain in an upright position as they raised the back for me. The contractions were coming more slowly now and each time I gave my best to push. I was also attached to a fetal monitor. However, it did not interfere with the labour because it didn't restrict my movements. On the contrary, the reassurance that it gave to the midwife that baby's heart was beating normally allowed her to buy more time for me on my behalf. I recall an obstetrician coming into the room twice to see if everything was alright and the midwife sending him away saying that everything was under control. At the beginning, the midwife, my guardian angel and the unidentified woman stood in front of me watching as my husband stood by my side. Everything seemed to be going well until the midwife decided to examine me and identified a swelling in the cervix which was preventing the baby from coming further down. She decided to intervene and inserted one or two fingers and waited for the next contraction. When the contraction came she tried to stretch the passageway for the baby: it was the most excruciating pain I had ever had in childbirth! The desire to push gave way to agonising panic. It is hard for me now to remember the sequence of events. I recall that after a few attempts at intervening in this way the midwife gave up and let me do things my way again since the baby's heart beat was fine. But squatting on the bed was not easy and I couldn't keep it up for long. I then began to feel weary and hungry. I knew I should have eaten more before leaving home! I requested food already knowing that it would be denied and yet the midwife's reply revealed sensitivity. She explained that irrespective of what my opinions were on the matter, hospital policy would not allow her to give me food. Could I have water? I was kindly offered water with sugar. (In the birth of my first daughter I had eaten chocolate and a spoonful of honey.) Time was pushing on and the midwife could see I was becoming tired. I can no longer recall who did what when; I just remember that once again I was examined and between the midwife and my guardian angel they decided that the same procedure would have to be repeated. Such agonising pain! I remember the unidentified woman asking why wasn't I gripping the bars, but they were too far down and I wanted human contact. So in the last minutes I gripped in desperate agony the hands and arms of my husband and guardian angel: how I didn't break their bones I don't know!! 


\section{DECEMBER}

It is difficult to give an accurate indication of time, but I would say that the last fifteen minutes or so were the most painful I have ever had in childbirth. The second stage of labour with the two girls has left me with the memory of pushing but without feeling pain. In this case, however, time was pushing on and the midwife had decided that I needed more help. My husband gently suggested that maybe the drip would be a good thing and I agreed. So the last moments of birth I was put on the drip and I even agreed to have my legs up in stirrups as the midwife (or was it my guardian angel?) continued with the stretching procedure each time I had a contraction. I was screaming out "no" and my whole body was in a state of denial which made it hard to push. But I realized that there was no way out now and so at the next contraction I pushed and pushed despite the pain. A couple more of these contractions and baby was born. I remember that with the last contraction I was in agony and about to stop pushing in order to resist the pain when the midwife said "don't give up now, the baby is about to be born!" With a mixture of despair and abandonment I carried on pushing until I felt a sudden rush and a sense of relief followed by the sight of a baby cradled in my guardian angel's arms and the sound of crying. "It's a boy! It's a boy!" exclaimed the midwife, "I'm going to win the lottery."

After I had been discharged from hospital I had a nightmare, which I feel, was related to those agonising last moments of the birth. The midwife had said that if she hadn't intervened the birth could have gone on for much longer. I was admitted to the hospital at 9.00 am and baby was born at 10.39 am. Looking back I suppose I achieved what I had wished: a natural and active birth with a degree of compromise on both sides.

How the midwife had been so sensitive to my approach was a mystery at the time. However, yesterday I discovered that a lot of background work had been carried out. A mutual friend explained to me that my guardian angel had contacted some of the midwives in the hospital beforehand, warning them that she would be accompanying someone who wanted a different kind of birth experience.

\section{DECEMBER}

My guardian angel came to visit and I was able to get her side of the story. It also felt therapeutic to go over the whole episode with her. As I had since suspected, she felt that I was told to push too early. He was a big baby and I wasn't totally dilated.

I discovered that the unidentified woman was a trainee doctor; apparently impressed with my attempts at a natural birth and only towards the end did she begin to worry. I now recall that towards the end, she said that if I had gone on the drip then it would have speeded up labour and diminished my suffering. It was at this stage that I began to feel that maybe I should go on the drip. I also found out that the obstetrician had told my guardian angel, out of our earshot, that he was taking no responsibility for the consequences of my refusal to be put on the drip (which 
contained medication to stimulate contractions). Yet, in sharp contrast to this, both my husband and guardian angel heard him state, inside the labour room, that obstetricians were too fearful and there were far too many interventions. I don't recall hearing this which highlights the difficulty of reproducing a full account of what happened at the top of the mountain. I was in no state to be aware of everything that was going on around me. Neither can I reproduce a full account of my own feelings at the time. The intensity of the experience is beyond words and images.

\section{JANUARY}

As I try to re-focus on my birth experience, I realize that if I had not been made to push too soon, I would have been spared those agonizing final moments. Yet I am still grateful that most of my wishes were taken into account. I was spared an episiotomy and only suffered superficial tearing; I was put on the drip so close to the end that, my guardian angel explained to me, it had no time to interfere with the birth; the stirrups were only used as a last resort also just before baby was born. I think what really impeded me from having a more active birth was the uncomfortable narrow bed. Nonetheless, I shall never forget that as I was wheeled to my bed in the ward, the midwife who had assisted me came and gave me a kiss on the forehead.

\section{Commentary}

Contrary to local practice, the midwives assisted me in labour without the presence of the doctors who were told that they were not needed. The degree to which the doctors considered this to be an anomaly became evident to me later, during a presentation of my birth narrative in the in-service training in the hospital where the birth had taken place. I was informed by the midwife who had assisted me that the doctors had written on my medical record that I had refused medical assistance. This is untrue on two accounts. Firstly, the midwives' assistance was of a medical nature and secondly, and more interestingly, I never actually requested the doctors to leave the room. It seems that I was not the only person eager to gain more control over the birth process: the midwives seized the opportunity to prove that their knowledge was not "peripheral" (Carapinheiro 1998). Yet, here too, we can see "authoritative knowledge" (Jordan 1993 [1978]) at work: surprised that I had been given the all clear to push before reaching full dilation, I still kept quiet and complied with the midwife.

I felt engulfed by the institutional environment and its routine procedures and was so overwhelmed by the birth experience that I lost a sense of my own initiative. One event I forgot to record in the narrative was at the end of the first day in hospital, when I asked one of the cleaning women if I should change the baby's nappy. She replied that she would go to ask a nurse. Already a mother of two children, surely I knew the answer! The cleaning woman may 
have known too but the fact that she went to consult a nurse exemplifies the power of hospitalised knowledge hierarchies at work.

\section{JANUARY (CONTINUED)}

I remained in hospital for forty-eight hours and missed the cosiness of being at home. The inappropriateness of routine hospital procedures became evident to me when both baby and I were woken up at midnight by a nurse, beginning her shift, to ask if everything was alright! The night before a nurse had insisted on squeezing one of my breasts with her cold hand to see if I had any milk. I tried pushing her hand away, but she insisted.

Hours after giving birth, another nurse had come in and started to massage my stomach to stimulate contractions. This was extremely painful and I had also tried to push her hands off. However, she too had insisted, informing me that it was very important that I do this massage, several times a day, to help the uterus contract back to its normal size. Otherwise, I risked infection. Frankly, I did not believe that it was necessary! I knew that breastfeeding had the same effect and every time baby fed I was already having very painful contractions. Why add to my misery? So I pretended to be following her advice whenever the medical staff enquired.

The morning I was discharged the nurse with the cold hand examined me, expressing concern that my uterus had not contracted sufficiently. Doubt crept in. "Maybe I didn't massage enough," I lied. However, a more senior nurse was brought in to see me and she exclaimed that for a third baby, I was doing very well...

How does the birth narrative of my third child come to a close? With mixed feelings of gratitude and indignation and with awareness that I have been unable to transmit the intensity of the birth experience... But my narrative will not stop here. I owe it to the Portuguese medical profession, and indeed to Portuguese mothers, to write a version in Portuguese.

\section{THE MOUNTAIN REVISITED}

What conclusions may be drawn after revisiting my birth narrative, over a decade later, in the light of current research on childbirth in Portugal? White's (2016) research in Lisbon shows how the practice of scheduling a date for delivery continues to be common in Portugal amidst women who can afford to receive ante-natal care from private obstetricians. More significant, however, is her analysis of "institutional time-ticking": how women are affected by the institutional categorizations of reproductive time. Even my first homebirth in the UK, for example, was not free from this pressure, since the midwives were in constant communication with the hospital when I was given an ultimatum: "either the baby is born within the next thirty minutes or we will have to transfer you to hospital." I recall asking "what will happen there?" and the sense of 
relief when the word C-section was not mentioned. The honey and chocolate provided the extra energy I needed and I gave birth within the half hour.

Yet in the case of the hospital birth in Portugal, the painful labour stimulating procedure that I was subjected to takes on a new meaning for me, in the light of White's (2016) and White and Queirós's (this volume) discussion of this practice, referred to in Portugal as the toque (the touch), since it has also been associated with "obstetric abuse." The sense of invasion experienced by their informants - not to mention the excruciating pain - was something that I had submitted to at the time, out of exhaustion and hunger and, as I discovered afterwards, as an inevitable consequence of an error of judgment of being encouraged to push too soon. Yet, I also wrote in the narrative that it had been a "natural birth," echoing the words proudly pronounced by the midwife who had attended me. Contrary to the experiences of women who gained belated agency through retrospective evaluation of the birth process (O'Dougherty 2013), I had a slight sense of belated loss of agency when I realized how I had uncritically accepted the midwife's description of the birth. This raises the question to what degree the toque has become accepted as a normal, "natural" practice in Portugal.

Yet, my description of the birth also reveals how there was compromise on both sides. Although the toque was invasive and painful, contrary to the informants in White's (2016) study, the rationale for the procedure was explained to me beforehand. Relevant here is the point made by Jordan (1997) of the need for greater "conversations" between women and health staff - and, I would add, not only during childbirth, but also in the form of reflexive exchanges and the sharing of birth narratives.

Although I wrote the narrative as a means of feeling more empowered, I was also becoming inquisitive, savouring my individual experiences as fieldwork. The way in which women spontaneously shared their birth stories with me revealed depths of pent up emotion. I was keen to share my narrative publically in order to make the bridge between the personal and the political, to promote debate at a time when active birth was not well known in Portugal, in order to challenge authoritative knowledge. The narrative became in this sense an auto-ethnography since it pointed beyond the self and aimed to make a political difference (Lockford 2002).

De Luca's (2012) auto-ethnography of the lived experience of pregnancy and medicalization in Portugal also recounts how her pregnant body induced acquaintances and strangers to share their childbirth experiences. She argues that this served to remember an important period in women's lives with other women whose pregnant bodies signified affinity: they would be able to "grasp their experiences from within" (De Luca 2012: 73). She noted how their "narratives reflected a construction of the self that had incorporated biomedical discourses. What came out of many of these memories were bodies that, at 
the end of their pregnancy, were unable to deliver if not with the intervention of surgery" (2012: 40). De Luca's auto-ethnography draws attention to how medicalized discourses impinge on both women and men's capacity to enjoy and share the sense of mystery and wonder of experiencing pregnancy.

The need to share positive childbirth experiences (Fenaroli et al. 2016; Thomson et al. 2017) has been acted upon in initiatives such as the Positive Birth Movement which began in Britain and now hosts a group in Lisbon. ${ }^{14}$ Nevertheless, since very few women's experiences are shared in their own words as birth narratives in Portugal, the positive and negative experiences of medical intervention are still not widely available for public consumption. Those analysed in this volume (White and Queirós, Fedele) elucidate the need for more research, calling into question the assumptions that homebirth is inherently dangerous and that medical intervention is always negative. Neither should it be presumed that women who opt for homebirth reject any kind of medical intervention. Recent research conducted by Santos and Augusto (2016) on the rare cases of planned contemporary homebirths in Portugal concludes that despite the desire to reduce medical intervention, the women's perceptions of social and medical risks resulted in a "reflexive consumption of medical technologies" (2016: 49).

To set up a mechanism whereby women and health professionals are encouraged to write and share birth narratives could constitute a significant contribution to the current anthropological research in Portugal on childbirth, helping to promote more reflexivity in all the parties involved. Rather than searching for analytical closure, the aim would be to approach the written texts as a series of "open cross-roads" (Brochner and Ellis 2002) to stimulate further debate, thus helping women to increase their sense of agency in pregnancy and childbirth.

\section{REFERENCES}

BALASKAS, Janet, 1991, New Active Birth: A Concise Guide to Natural Childbirth. London, Thorsons.

BLONDEL, B., et al., 2016, "Variations in rates of severe perineal tears and episiotomies in 20 European countries: a study based on routine national data in Euro-Peristat Project", Acta Obstetricia et Gynecologica Scandinavica, 95: 746-754.

BROCHNER, Arthur P., and Carolyn ELLIS (eds.), 2002, Ethnographically Speaking: Autoethnography, Literature and Aesthetics. New York, AltaMira Press.

14 See < http://www.positivebirthmovement.org > (last access in October 2018). 
BUTZ, David, and Kathryn BESIO, 2009, "Autoethnography", Geography Compass, 3 (5): 1660- 1674.

CARAPInHeIro, Graça, 1998, Saberes e Poderes no Hospital: Uma Sociologia dos Serviços Hospitalares. Porto, Edições Afrontamento.

CHALLINOR, Elizabeth Pilar, 2012, "O parto hospitalar e a auto-etnografia: o desafio de novos territórios", in Alice Delerue Matos and Maria Johanna Schouten (eds.), Sistemas, Mediações e Comportamentos em Saúde. Ribeirão, Editora Húmus, 145-162.

COXON, Kirstie, Jane SANDALL, and Naomi J. FULOP, 2014, "To what extent are women free to choose where to give birth? How discourses of risk, blame and responsibility influence birth place decisions", Health, Risk \& Society, 16 (1): 51-67.

DAVIS-FLOYD, Robbie E., 1992, Birth as an American Rite of Passage. Berkeley, CA, University of California Press.

DAVIS-FLOYD, Robbie E., and Carolyn F. SARGENT (eds.), 1997, Childbirth and Authoritative Knowledge: Cross-Cultural Perspectives. Berkeley, University of California Press.

DE LUCA, Francesca, 2012, (Eu) Somos: Lived Experience of Pregnancy and Medicalization. Lisbon, ISCTE - Instituto Universitário de Lisboa, MA dissertation in Anthropology.

DH - DEPARTMENT OF HEALTH, 1993, Changing Childbirth: Report of the Expert Maternity Group. London, HMSO.

DH - DePARTMENT OF HEALTH, 2007, Maternity Matters: Choice, Access and Continuity of Care in a Safe Service. London, The Stationery Office.

ELLIS, Carolyn, and Douglas FLEMONS, 2002, "High noon: a 'fictional dialogue' ", in A.P. Brochner and C. Ellis (eds.), Ethnographically Speaking: Autoethnography, Literature and Aesthetics. New York, AltaMira Press, 344-356.

FENAROLI, Valentina, et al., 2016, “Italian women's childbirth: a prospective longitudinal study of delivery predictors and subjective experience", Journal of Reproductive and Infant Psychology, 34 (3): 235-246.

FOUCAUlt, Michel, 1991, Discipline and Punish: The Birth of the Prison. London, Penguin Books.

INGOLD, Tim, 2014, “That's enough about ethnography!”, HAU: Journal of Ethnographic Theory, 4 (1): 383-395.

JOAQUIM, Teresa, 2006, Cuidar dos Outros, Cuidar de Si: Questões em Torno da Maternidade. Lisbon, Livros Horizonte.

JORDAN, Brigitte, 1993 [1978], Birth in Four Cultures: A Cross-Cultural Investigation of Childbirth in Yucután, Holland, Sweden and the United States. Prospect Hills, IL, Waveland Press ( $4^{\text {th }}$ edition).

JORDAN, Brigitte, 1997, "Authoritative knowledge and its construction”, in R. E. Davis-Floyd and C.F. Sargent (eds.), Childbirth and Authoritative Knowledge: Cross-Cultural Perspectives. Berkeley, University of California Press, 55-79.

KAY, Lesley, 2016, Engaging with the "Modern Birth Story" in Pregnancy: A Hermeneutic Phenomenological Study of Women's Experiences across Two Generations. Preston, University of Central Lancashire, PhD thesis in Philosophy.

LAZARUS, Ellen, 1997, "What do women want? Issues of choice, control, and class in american pregnancy and childbirth", in R.E. Davis-Floyd and C. F. Sargent (eds.), Childbirth and Authoritative Knowledge: Cross-Cultural Perspectives. Berkeley, University of California Press, 132-158.

LOCKFORD, Lesa, 2002, "Breaking habits and cultivating home", in A.P. Brochner and 
C. Ellis (eds.), Ethnographically Speaking: Autoethnography, Literature and Aesthetics. New York, AltaMira Press, 76-86.

MARTIN, Emily, 1987, The Woman in the Body: A Cultural Analysis of Reproduction. Boston, Beacon Press.

NOBRE, Kátia, 2014, Empowerment through Reading: Advocacy for Improving Cape Verdeans' Reading Culture. Praia, University of Cape Verde, dissertation for a degree in English Studies.

O'DOUGHERTY, Maureen, 2013, "Plot and irony in childbirth narratives of middle-class Brazilian women”, Medical Anthropology Quarterly, 27 (1): 43-62.

PELIAS, Ronald J., 1999, Writing Performance: Poeticizing the Researcher's Body. Carbondale, IL, Southern Illinois University Press.

REED-DANAHAY, Deborah, 1997, "Introduction", in D. Reed-Danahay, Auto/Ethnography: Rewriting the Self and the Social. Oxford, Berg, 1-20.

RYDING, Elsa Lina, et al., 2015, "Fear of childbirth and risk of cesarean delivery: a cohort study in six European countries", Birth Issues in Perinatal Care, 42 (1): 48-55.

SANTOS, Mário, J.D.S, 2014, “Trajetórias de desinstitucionalização do parto: a rejeição da hegemonia biomédica na opção pelo parto em casa", in Atas do VII Congresso Português de Sociologia. Lisbon, Associação Portuguesa de Sociologia.

SANTOS, Mário J.D.S., and Amélia AUGUSTO, 2016, “'Se estava tudo bem, porque é que eu havia de ir a uma obstetra?' Identidade, risco e consumo de tecnologia médica no parto domiciliar em Portugal”, Sociologia, Problemas e Práticas, 82: 49-67.

SCAMELL, Mandie, 2011, "The swan effect in midwifery talk and practice: a tension between normality and the language of risk", Sociology of Health \& Illness, 33 (7): 987-1001 .

SCHOUTEN, Maria Johanna, 2012, "Nascer num ambiente familiar ou clínico: tendências de medicalização e de desmedicalização do parto", in Atas do VI Congresso Português de Sociologia, Lisbon, Associação Portuguesa de Sociologia.

THOMSON, Gill, et al., 2017, "Negative impressions of childbirth in a North-West England student population”, Journal of Psychosomatic Obstetrics \& Gynecology, 38 (1): 37-44.

TREVATHAN, W.R., 1997, "An evolutionary perspective on authoritative knowledge about birth", in R.E. Davis-Floyd and C.F. Sargent (eds.), Childbirth and Authoritative Knowledge: Cross-Cultural Perspectives. Berkeley, University of California Press, 80-90.

WAGNER, Marsden, 1997, "Confessions of a dissident", in R.E. Davis-Floyd and C.F. Sargent (eds.), Childbirth and Authoritative Knowledge: Cross-Cultural Perspectives. Berkeley, University of California Press, 366-393.

WHITE, Joanna, 2016, “'But isn't it the baby that decides when it will be born?': temporality and women's embodied experiences of giving birth”, Cambridge Journal of Anthropology, 34 (1): 72-86.

WHITE, Joanna, and Maria Johanna SCHOUTEN, 2014, "Normal birth as a cultural phenomenon: background to the proceedings", in Joanna White and Maria Schouten (eds.), Normal Birth: Experiences from Portugal and Beyond/O Parto Normal: Experiências de Portugal e Além-Fronteiras. Braga, CICS, and Lisbon, CRIA, 13-20. 